\title{
Taxation and Budget Reform Commission (TBRC) Constitutional Amendment 6: Assessment of Working Waterfront Property Based upon Current Use ${ }^{1}$
}

Rodney L. Clouser ${ }^{2}$

A series of 16 fact sheets has been written on statutory and constitutional proposals adopted by the Taxation and Budget Reform Commission (TBRC). The publications in this series can be accessed at http://edis.ifas.ufl.edu. Fact sheets FE733 through FE741 address statutory changes and fact sheets FE742 through FE748 address constitutional amendments. These fact sheets should not be considered as an all-inclusive assessment of the statutory or constitutional changes recommended by the Taxation and Budget Reform Commission. Some details of proposed changes may not have been discussed due to space limitations. These fact sheets are not intended as a replacement for personal knowledge about actual or proposed changes but are a guide to inform the public on the issues.

\section{Introduction}

According to Article XI, Section 6 of the Florida Constitution, "Beginning in 2007 and each twentieth year thereafter there shall be established a taxation and budget reform commission." The Taxation and Budget Reform Commission (TBRC) is charged with the following: 
The TBRC can make statutory recommendations to the Florida Legislature and directly place proposed constitutional amendments on the ballot for approval or rejection by Florida voters.

Fact sheets in this series will present information on constitutional amendments the TBRC has placed on the fall 2008 general election (2008 November presidential election) ballot. The commission was charged with holding public meetings to carry out their responsibilities and has been meeting since March of 2007. The committee concluded their work and transmitted their proposed constitutional amendments to the Florida Secretary of State on April 28,2008 . All the proposed constitutional amendments required an affirmative vote of at least two-thirds of the voting members of the commission (17 members). In total, the TBRC approved eleven constitutional proposals. The committee combined these eleven proposals into seven constitutional amendments. The amendments passed by the TBRC will be numbered Amendments 3 through 9 on the fall ballot (Amendments 1 and 2 are reserved for two other 2008 amendment proposals, one approved by the legislature and the other a citizen initiative).

The TBRC amendments placed on the 2008 general election ballot are listed by ballot title below:

- Amendment 3: Changes and Improvements Not Affecting the Assessed Value of Residential Real Property

- Amendment 4: Property Tax Exemption of Perpetually Conserved Land; Classification and Assessment of Land Used for Conservation

- Amendment 5: Eliminating State Required School Property Tax and Replacing with Equivalent State Revenues to Fund Education

- Amendment 6: Assessment of Working Waterfront Property Based upon Current Use

- Amendment 7: Religious Freedom

- Amendment 8: Local Option Community College Funding

- Amendment 9: Requiring 65 Percent of School Funding for Classroom Instruction; State's Duty for Children's Education
Each fact sheet in this series will provide details regarding one of the amendments, submitted to the Secretary of State, in the order they will appear on the ballot (Amendment 3, Amendment 4, Amendment 5, Amendment 6, Amendment 7, Amendment 8, and Amendment 9).

\section{Proposed Amendment 6}

When people go to their polling places in November 2008, they will see information on the amendment, references to the portion of the constitution that will be altered, sponsor of the amendment, the ballot title, and the ballot summary. The information for Amendment 6 will be similar or identical to the following and the ballot title and ballot summary are direct quotes:

Proposed Constitutional Amendment No. 6: ARTICLE VII, SECTION 4; ARTICLE XII, NEW SECTION (Taxation and Budget Reform Commission)

\section{Ballot Title: ASSESSMENT OF WORKING WATERFRONT PROPERTY BASED UPON CURRENT USE}

Ballot Summary: Provides for assessment based upon use of land used predominantly for commercial fishing purposes; land used for vessel launches into waters that are navigable and accessible to the public; marinas and drystacks that are open to the public; and water-dependent marine manufacturing facilities, commercial fishing facilities, and marine vessel construction and repair facilities and their support activities, subject to conditions, limitations, and reasonable definitions specified by general law.

\section{Effect of Amendment 6}

Amendment 6 is a combination of three proposals passed by the TBRC. The basis of the amendment is that working waterfronts be assessed at current use rather than at just value or market value as required by current law. The amendment defines working waterfronts as:

- Land used predominantly for commercial fishing purposes. 
- Land that is accessible to the public and used for vessel launches into waters that are navigable.

- Marinas and drystacks that are open to the public.

- Water-dependent marine manufacturing facilities, commercial fishing facilities, and marine vessel construction and repair facilities and their support activities.

\section{Impact of Amendment 6}

Since this amendment affects ad valorem taxes, its impact is on local units of government (counties, municipalities, etc.). State staff analysis indicates that the change in assessment would not apply to school district tax levies. Assessing value based on current use rather than just value or market value should lower assessments significantly. This would lower taxes collected by units of local government unless they raised millage rates. Passage of the amendment as written would result in a tax shift from people who own working waterfronts (as defined above) to all other property owners. In general, the thought is that while tax payments for other property owners would only increase a small amount, tax savings to owners of working waterfront properties could be significant, thus assisting in keeping the property in its current use rather than it being sold and/or developed.

If the proposed amendment is passed, it would not become effective until January 1, 2010, which implies that local units of government would not be impacted until fiscal year 2010-2011. Still, units of local government may be concerned about programs that remove value from tax rolls. A reduction in taxes, compared to current law, would impact the type and quality of services that local units of government could provide to their respective citizens. Most of the impacts would likely be in coastal areas although the definition of working waterfronts is not limited to coastal areas. In reality, working waterfront landowners have probably experienced the largest increases in assessed values compared to those of other property classes, especially those in coastal counties.
Some questions you might consider to help determine your position on the proposed amendment include:

- How much value will be removed from tax rolls of local units of government?

- Would the tax reduction be large enough of an incentive to encourage working waterfront owners to keep the land in its current use?

- Should property owners be willing to pay more in property taxes to fund the program if millage rates increase?

- Should there be a rollback or tax recapture program for working waterfront landowners if the land is not kept in that use for some specified period of time?

- Is there another more equitable program that would provide tax relief to working waterfront landowners since all Florida residents and visitors to the state enjoy the benefits of working waterfront properties (i.e., boat launching privileges, fresh seafood, lake and ocean access, etc.)?

Questions such as these may help you determine your support or lack of support for the amendment.

\section{Summary}

Adoption of the constitutional amendment requires a vote in favor of the amendment by a minimum of $60 \%$ of those voting. Additionally, amendments are subject to legal challenges and could possibly be removed from the ballot if successfully challenged.

Voters in Florida have the opportunity to change the state constitution during the 2008 general election. The intent and purpose of the information contained in this fact sheet on Amendment No. 6 is not to tell individuals how to vote. Rather, the fact sheet is provided to help voters become more informed. Informed voters need to be more knowledgeable of the ballot issue on which they are voting than just by reading a ballot title and ballot summary. Ballot titles and summaries do not inform voters in significant detail, nor do they inform voters 
on policy implications of what a yes or no vote implies. Because informed voters make informed public policy decisions, your challenge as a voter and a citizen is to become informed and then, by casting your ballot, make your values and preferences known.

\section{References}

Florida Department of State, Division of Elections. 2008. Initiatives / Amendments / Revisions. Division of Elections, Florida Department of State, Tallahassee, FL (May). http://election.dos.state.fl.us/initiatives/ initiativelist.asp

Florida Taxation and Budget Reform Commission. 2008. A resolution proposing an amendment to Section 4 of Article VII and the creation of a new section in Article XII of the State Constitution. TBRC, Tallahassee, FL (May).

http://www.floridatbrc.org/pdf/

CP6_8_34E2Final2.pdf

Florida Taxation and Budget Reform Commission. 2008. Staff Analysis and Economic Impact Statement. TBRC, Tallahassee, FL (May). http://www.floridatbrc.org/pdf/

4_8_08CSforCP6_8_34StaffAnalysisPreStyleDraftin g.pdf

Florida Taxation and Budget Reform Commission. 2008. Transmittal letter. TBRC, Tallahassee, FL (May). http://www.floridatbrc.org/pdf/ CPTransmittalLetter.pdf 